УДК 355.098.(477)

DOI: $10.33099 / 2707-1383-2019-33-3-5-22$

Бенчук В.О., аспірант Національного університету «Острозька академія» (м. Острог)

\title{
СУСПІЛЬНО-ПОЛІТИЧНЕ ТА СИЛОВЕ ПРОТИСТОЯННЯ В УКРАЇНСЬКОМУ МІСТІ МАРІУПОЛЬ НАВЕСНI 2014 РОКУ
}

Подї, щзо мали місце на Сході України після Майдану та захоплення півострова Крим Росією, більшістю науковців та експертів розиінюються як сепаратистський або проросійський рух, який завдяки втручанню РФ переріс у збройний конфлікт. Але чіткого розмежування між цими поняттями у трактуванні так і немає, оскільки ці подї недостатньо вивчені та переосмислені. Тому у статті на прикладі багатотисячного міста Північного Приазов'я Маріуполь відображено та проаналізовано суспільно-політичне та силове протистояння на Донбасіна навесні 2014 p.

Ключові слова: ДНР, Маріуполь, мітинг, проросійські активісти, протистояння, референдум.

Силова акція на Майдані 18-20 лютого 2014 р. призвела до втечі президента В. Януковича та зміни влади в державі. Це викликало суспільно-політичне протистояння на Донбасі між прихильниками та противниками зміни центральної влади у Києві. Ці події відбувалися в умовах збройної агресії
РФ на півострові Крим та втручання російських спецслужб у протистояння на Донбасі. Внаслідок цього на Сході України розпочався збройний конфлікт, який виник не без участі суспільно-політичних сил українського сходу.

Суспільно-політичне та силове протистояння на Донбасі залишається недо- 
статньо дослідженою темою. Ї̈, зокрема, вивчають В. Головко та Л. Якубова, які у співавторстві в колективній монографії дійшли до висновку, що місцева влада хотіла скористатися виступами маргінальних політичних сил та груп з метою збереження своєї влади та впливу, але «актори на сепаратистській сцені Донбасу були начебто старі («люди» місцевих авторитетів), тазамовникив них вжебули інші - у Москві» [1, с. 644-645]. В іншій праці Л. Якубова вважає, що стихійний протест виник проти порядків, встановлених місцевою владою, але він майстерно був перенаправлений проти Києва 3 метою приєднання цих регіонів до РФ [44, с. 207-208]. Ця думка тиражувалася в наступних працях написаних авторкою у співавторстві з іншими науковцями [41].

Британський та канадський політолог українського походження Т. Кузьо у своєму дослідженні стверджує, що очільники Партії регіонів мали на меті використати суспільні протести для тиску на Київ, але іiі розпад спричинив політичний вакуум, який заповнили промосковські сили, підтримані прихованим російським вторгненням [20, с. 322]. Г. Перепелиця події весни 2014 р. розглянув у поєднанні суспільно-політичного та військового вимірів.
Він вважає, що російські диверсанти скористалися ініціативою протестувальників та їх неорганізованістю, очоливши їх виступи та направивши у потрібний напрямок, згідно 3 планом та логікою гібридної війни [26, с. 563].

Низка інших дослідників - М. Віхров [6], Д. Казанський [18; 19], Б. Буткевич [4; 5], С. Шибалов [43], І. Лосєв [17] у своїх розвідках дослідили процеси, які відбувалися в донецькому соціумі внаслідок «російської весни» 2014 р. Вони охарактеризували та проаналізували суспільну базу «ДНР». Останню підтримували представники місцевої влади, різні маргінальні суспільно-політичні сили, частина місцевого населення, антисоціальні елементи — криміналітет, наркомани, пияки, якими скористалися російські спецслужби та їх політичне керівництво.

Силове протистояння у Маріуполі було висвітлено у праці, написаній авторським колективом, «Біла книга антитерористичної операції на Сході України (2014-2016 рр.)», де зазначено, що зі штурмом української в/ч № 3057 НГУ колаборантами «ДНР» у Маріуполі почався збройний конфлікт [3, с. 23]. С. Марко також розкрив військову боротьбу за міс- 
то, акцентуючи увагу на проблемах, 3 якими стикнулися українські військові у протистоянні за Маріуполь [22]. Дослідженням збройного конфлікту на материковій частині України також займаються представники країни-агреcopa - А. Циганков, який відображає «русский взгляд» на ці події, фальсифікуючи історичні факти та події [42].

Мета статті - 3'ясувати особливості суспільно-політичного та силового протистояння в українському місті Маріуполь в лютому — червні 2014 р.

23 лютого 2014 р. 3 ініціативи Маріупольської громадської організації «Искренность» (сфера діяльності якої - благодійна допомога дітям-сиротам, багатодітним сім'ям, дітям війни, спонсором якої останні роки був Маріупольський металокомбінат ім. Ілліча) [25] на Театральній площі відбувся мітинг, на якому звучали заклики до федералізації. Водночас інший мітинг відбувався біля пам'ятника В. Леніну - на підтримку Майдану. Дізнавшись про останній, протестувальники 3 площі вирушили туди, проте прихильники Майдану на той момент уже розійшлися. Тому свій мітинг вони продовжили на цьому місці, виступаючи з вимогами захис- ту південно-східної України від «фашистів». Тут також було здійснено акт насильства проти активіста Майдану Є. Корабльова, якого побили $[27$, с. 4]. На фоні тогочасних подій у Києві та Маріуполі, наступного дня у міській раді зібралися представники суспільно-політичних сил і громадських організацій. Усі вони виступили за порядок і злагоду в місті [27, с. 2].

Але 1 березня відбулися нові мітинги. Найчисельніший був проведений біля пам'ятника В. Леніну прихильниками Майдану, яких підтримали міські осередки партій «УДАР» та «Батьківщина». Вони виступили за єдину Україну, а також проти введення на іï територію російських військ. Інший відбувся біля пам'ятника В. Висоцькому, організований Комуністичною партією України (КПУ). На нього учасники прийшли з російськими прапорами. Вони засуджували «нелегітимну центральну владу в Києві, організовану в результаті збройного перевороту», висловили підтримку жителям Криму та оголосили резолюцію. Водночас біля міської ради відбувся ще один мітинг, також під прапорами РФ і СРСР, до якого згодом приєдналися протестувальники з мітингу біля пам'ятника 
В. Висоцькому. Узв'язку зцим наступногодня буласкликанапозачерговасесія міської ради. Вона відбувалася на фоні двох мітингів - проросійського та українського. Проросійські мітингувальники висловилися за «співробітництво з РФ і з закликами ввести в Приазов'я миротворчі війська братського народу для захисту південносхідного населення від безчинств коричневої чуми». Вони організували звернення на ім'я президента РФ В. Путіна з проханням надати підтримку місту [28, с. 3].

На сесії розглядали резолюцію, складену проросійськими активістами на мітингу 1 березня. Проти неї виступили депутати фракції «Фронту Змін», які пропонували засудити присутність іноземних військ на території України. Проте їх не підтримали, натомість було прийнято звернення до Верховної Ради України, що віддзеркалювало вимоги проросійських сил:

- відновити дії Закону України «Про засади державної мовної політики»;

- припинити прояви націоналізму, фашизму та розпалення міжнаціональної ворожнечі;

- внести зміни до Конституції України щодо децентралізації;
- прийняти дієві кроки для налагодження дружніх та добросусідських відношень з РФ, у першу чергу в економічній та політичній сферах [28, с. 1-2]. 5 березня відбулася нова хвиля протестів - i за цілісність України, і 3 проросійськими гаслами. На мітингу за єдину Україну було підготовлене звернення до ВРУ, Кабміну, Державної Думи РФ, Ради Федерації Росії та до Організації з безпеки та співробітництва в Європі. У ньому зазначалося, що жителі Маріуполя за єдину і неподільну Україну та за мир і добросусідські відносини з РФ [23]. Згодом на цьому ж місці, де був український мітинг, громадська організація «Русский союз Донбасса» організувала свій протест. Його учасники вимагали проведення референдуму та в черговий раз просили президента РФ захистити російськомовне населення [8].

Організаційна підготовка «референдуму» в Криму, під виглядом якого РФ здійснювала окупацію півострова, призвело до нових заворушень у Маріуполі. 15 березня низка суспільних та політичних організацій — «Антифашистський комітет», «Народное освободительное движение Украины», «Народ Мариуполя», «Народный ко- 
митет Донбасса», партії «Руський блок України» та КПУ знову організували масовий протест [10]. На ньому вимагали проведення референдуму з метою «підтримки курсу на входження до Митного Союзу і всебічну інтеграцію з братерськими народами країн СНД», a інші пропонували приєднатися до складу РФ. Наступного дня «Русский союз Донбасса» також організував свій мітинг, на якому висловив свою позицію, що він за єдину Україну, але без нацизму. Пропонувалося також залучити Росію як гаранта безпеки жителів від «олігархічного радикально-націоналістичного перевороту» [29, с. 3].

Активізація проросійських сил призвела до скликання 18 березня місцевою владою круглого столу. На ньому були висловлені різні позиції: представник фракції Партії регіонів закликав до конструктивного діалогу з метою зменшення напруги у місті; депутат від «Фронту Змін» засуджував участь у мітингах іноземних громадян; член КПУ В. Дейнес пропонував у виконком міської ради ввести представників громадськості з правом вето; представник проросійських мітингувальників Д. Кузьменко заявляв про необхідність надання Донецькій області автономії.
Всі висловлені пропозиції взяли до уваги для напрацювання спільної позиції, яку планувалося розглянути 25 березня на сесії міської ради $[12$, с. 2]. Обговорення відбувалося під тиском мітингувальників із прапорами РФ та КПУ. Як заявила одна із учасниць цього дійства, потрібно провести референдум, на якому жителі Маріуполя самі мають вирішити статус свого регіону - чи залишити все як $\epsilon$, чи приєднатися до складу РФ, чи проголосити автономію, оскільки вони хочуть отримуватигідну заробітну плату й мати економічнустабільність у регіоні [7].

22 березня перед міською радоювідбувся мітинг, але вперше без російських прапорів, а з символікою СРСР, який продемонстрував, що громадськість Маріуполя розділена на кілька таборів у баченні суспільно-політичного розвитку, а не лише на український та проросійський [9]. Протестувальники виступали на підтримку експрезидента В. Януковича, записали відеозвернення до нього, в якому заявили, що він $є$ легітимним президентом та просили його захистити українських громадян $[13$, c. 2$]$.

Напередодні сесії був зібраний черговий круглий стіл, де було доопрацьо- 
вано спільне рішення та заплановані наступні кроки для розв’язання суспільно-політичної напруги у місті:

- проведення соціологічного дослідження в регіоні щодо стабілізації політичної ситуації;

- створення громадської ради при виконавчому комітеті з повноваженнями контролю діяльності органів державної та місцевої влад;

- прийняття депутатським корпусом звернення до ВРУ, в якому пропонувалося надати російській мові статус державної, провести децентралізацію влади й бюджету, прийняти закон про муніципальну поліцію тощо. [30, с. 3]. На проведеній 28 березня сесії відбувся обмін думок і було прийнято звернення до ВРУ. Більшість політичних сил і громадських організацій виступали за збереження миру та порядку у місті, відстоювання інтересів останнього. Проте «народний мер», обраний напередодні, вчергове заявив, що містяни окремо можуть налагодити стосунки з РФ і закликав до відділення від України [31, с. 1-2].

Попри підтримку міської влади чергового звернення до ВРУ, що відображало проросійські вимоги, спротив промосковських сил не припинився. Це було пов'язано 3 розмитим баченням остаточної мети цього руху: хтось виступав за приєднання до РФ та закликав російська війська до міста, хтось хотів автономний статус, а інші - суверенітету. Проголошення так званої Донецької Народної Республіки (ДНР) дало новий поштовх у протистоянні в місті між проросійськими та українськими активістами. Відбулися мітинги під українськими прапорами, а мер міста Ю. Хотлубей озвучив офіційну заяву, в якій наголосив, що маріупольська громада виступає за мир і порядок та єдину й цілісну Україну [21].

Суспільно-політичне протистояння переросло у збройний конфлікт, коли при узгоджених діях російських спецслужб із бойовиками було проведене одночасне захоплення державних установ у низці міст Донбасу - Apтемівську (з 2016 р. Бахмут), Краматорську, Слов'янську, Красному Лимані (з 2016 р. Лиман). Це призвело до спільної заяви авторитетних політичних і суспільних діячів Маріуполя, в якій зазначалося, що вони за децентралізацію, російську мову, але категорично проти насилля та озброєних людей на вулицях [14, с. 1]. Але воно не зупинило представників «ДНР», 
які намагалися 16 квітня штурмом військової частини Національної гвардії України (НГУ) № 3057 взяти місто під свій повний контроль [3, с. 23].

На час цих подій вже була сформована мета проросійського руху — державна самостійність «ДНР». Хоча згодом, у день так званого референдуму, голова центральної виборчої комісії останньої Р. Лягін заявив, що після нього Донецька область буде у складі України. Ціль цього «референдуму» заявити - «світу, що ми хочемо змін» [24]. Очевидно, спочатку іiі керівники боялися брати на себе відповідальність та очікували коли РФ почне реалізовувати «кримський сценарій» на Донбасі, а протестувальники, закладаючи власний сенс у своїх діях, у силу обставин стали заручниками ситуації та фактично колаборантами [11, с. 35].

Попри успішну оборону українських військових в/ч №3057 НГУ, бойовики «ДНР» захоплювали державні установи та встановлювали свій контроль над містом [32, с. 2]. На травневі свята вони повісили свої прапори на установах управління міліції та прокуратури, змусивши керівника правоохоронних органів написати заяву про звільнення.

Вночі 33 на 4 травня колаборанти перекрили центр міста, підпалили відділення «ПриватБанку» та шини на перехрестях проспекту Леніна (проспект Миру) з вулицею Казанцева й останньої з проспектом Нахімова, відкрили стрільбу з автоматичної зброї. А біля міської ради представники «ДНР» приготувалися до оборони, адже по їх інформації українські силовики готували зачистку міста [33, с. 1].

Дестабілізація обстановки у місті змусила українське військове керівництво, для відновлення правопорядку та спокою, підготувати операцію по звільненню міської ради. Для цього планувалося залучити сили батальйону особливого призначення Міністерства внутрішніх справ (МВC) «Азов» та 72-ї Окремої механізованої бригади (ОМБр). Проте вночі 6 травня колаборанти покинули державну установу, а наступного дня їі знову захопили, знявши український прапор та повісивши низку інших — «ДНР», міста Маріуполя, РФ, СРСР [34, с. 2, 18]. Навколо міста також були встановлені 10 блокпостів, якими «ДНР» заблокувало під’їзди до міста [22, с. 202].

Поворотним моментом в опануванні «ДНР» ситуацією в місті стали події 9 травня. Тоді бойовиками було 
захоплено міське управління міліції. Офіцери, котрі проводили нараду в цей момент, забарикадувалися та викликали підмогу [1, с. 650]. На місце події прибули спецпідрозділи «Азов», «Омега» та військовики. Вони вступили у бій з бойовиками, але на місце зіткнення прибув натовп людей 3 мітингу, який почав нападати на українських військових. У результаті постраждалиі цивільні особи $[35$, с. 1$]$.

На сторінках газети «Приазовський робочий» були опубліковані спогади свідків тих подій. Із них випливало, що біля управління міліції ще до прибуття українських військових 3'явилися «невідомі в масках, можливо, якість терористи», які відкрили вогонь у бік міліціонерів. Саме 3 ними військовики, котрі прибули на підмогу останнім, розпочали перестрілку. Інші учасники подій розповідали, що перехожі викрикували образливі слова в адресу українських військових, намагаючись їх спровокувати. Але вони не звертали на них уваги. Тому натовп почав наближатися до них. Аби зупинити його, українські військові почали стріляти у повітря, а коли це не подіяло, під ноги. Кулі, попадаючи в асфальт, ри- кошетили та ранили навколишніх людей [40, с. 18]. У зв’язку із цими трагічними подіями керівництво антитерористичної операції прийняло рішення відвести українські війська 3 міста, щоб уникнути напруження та нових жертв [22, с.203].

В результаті цієї провокації мешканці Маріуполя масово пішли на так званий референдум, налякані недавніми подіями. Явка на «референдум» склала 43,45\%, з яких 92,91\% проголосували за суверенітет «ДНР» $[35$, с. 2]. У місті склалося двовладдя, оскільки 3 однієї сторони була влада «ДНР», а з іншої продовжувала працювати українська, на яку постійно тиснули представники останньої. Тому місцева влада для стабілізації ситуації виступила ініціатором підписання Меморандуму про порядок і безпеку (Спільні ініціативи по забезпеченню громадської безпеки в місті Маріуполь). Його підписантами були місцева влада та міліція, директори двох металургійних комбінатів ім. Ілліча та Азовсталь, якими володіла група Метінвест Р. Ахметова, низка громадських організацій та «народний мер» Маріуполя [1, с. 651]. У Меморандумі зазначалося: «Події 9 травня показали, що збройне протистояння - 
це шлях до загибелі людей... Ці події не мають повторитися. Наш пріоритет - мир у Маріуполі, спокійне життя міста, забезпечення стабільної роботи промисловості та комунальних підприємств» [36, с.1].

Але цей союз був не життєздатним. Його не схвалили місцеві прихильники «ДНР», які вимагали негайної відставки мера Ю. Хотлубея [37, с.1]. Згодом проти цієї співпраці виступили і підписанти Меморандуму. Група Метінвест рішуче виступила проти керівництва «ДНР» та оголосила безстрокову акцію «Голос Донбасу». Акція стартувала 3 офіційного звернення Р. Ахметова, в якому він заявив: «Скажіть мені, будь ласка, хто в Донбасі знає хоч одного представника цієї ДНР?... Ходити 3 автоматами по містах Донбасу це що - відстоювання прав донеччан перед центральною владою?... Ні! Це боротьба проти жителів нашого краю! Це - боротьба проти Донбасу! Це - геноцид Донбасу!» [2].

Приводом для такої заяви стали дії «ДНР». На 19 травня у Маріуполі планувався багатотисячний мітинг «за мир, порядок і роззброєння», але представники «ДНР» почали органі- зовувати різні провокації, зірвавши таким чином мирний марш. Також цього дня в Донецьку бойовики захопили управління залізничної дороги, що призвело до зупинки вантажних перевезень [15, с. 1-2]. Тому на підприємствах Р. Ахметова стартувала безстрокова акція та мітинги. На них звучали різкі заяви в адрес «ДНР» - «ніякої віртуальної Донецької народної республіки» [38, с. 4], вона «проявила своє справжнє обличчя. Це обличчя бойовика, обличчя терориста» $[15$, с. 1]. Але на цьому дії групи Метінвест не припинились. У Маріуполі вона допомогла організувати та провести позачергові вибори Президента України, надавши свій транспорт та водіїв виборчим комісіям, а також забезпечивши їх охорону. Явка на виборах була низькою у порівнянні з минулими виборами та так званим референдумом. На двох територіальних виборчих округах (ТВО), які знаходилися в Маріуполі, містяни прийшли висловити своє виборче право: на одному ТВО 1-3,39\%, на іншому 15,59\%. Як стало відомо згодом, на обох округах переміг П. Порошенко $[39$, c. 1,5$]$. 
Але терор у місті не припинився. Постійне мародерство, віджимання бізнесу та підприємств, щомісячні побори, викрадення людей тощо зробило життя містян нестерпним [16, с. 2]. 13 червня Маріуполь був звільнений від бойовиків. 72-га ОМБр взяла Маріуполь в кільце, а підрозділи Міністерства внутрішніх справ «Азов» та «Дніпро-1» разом із 1-ю бригадою НГУ провели зачистку. Їм чинили опір близько 70 бойовиків, проте більшість із них втекли ще до початку операції. У результаті місто було звільнено від «російської весни» та повернено у мирне життя [22, c. 204].

Таким чином, аналіз суспільно-політичного та силового протистояння в українському місті Маріуполь довів, що події на Донбасі у 2014 р. це складна та неоднозначна сторінка в українській історії, яка ще потребує грунтовного та неупередженого дослідження. 3'ясовано, що проросійський суспільно-політичний рух підтримувала частина маріупольського суспільства разом із маргінальними організаціями та політичною партією КПУ, які виступили колаборантами. Але їх мета була не сформована, тому що кожен переслідував свою ціль- хтось запрошував російські війська у Маріуполь, інша частина прагнула приєднання до РФ, дехто прагнув автономії для Донбасу у складі України. Місцева влада, у свою чергу, прагнучи зберегти спокій та безпеку у місті, одночасно підтримувала частину вимог проросійського руху, щоб тиснути на центральну владу і зберегти таким чином свій вплив та позицію. Але на противагу проросійському руху частина жителів Маріуполя, за підтримки політичних партій, керівники яких були при владі у Києві, виступали за територіальну цілісність України та проти агресії РФ.

Проте суспільно-політичне протистояння переросло у силове, коли диверсійні групи, керовані російськими спецслужбами, окупували низку міст Донбасу, що призвело до утворення «ДНР». Доповнено, що захоплення бойовиками Маріуполя вдалося завдяки організованій ними провокації 9 травня, коли під час силового протистояння між українськими військовиками та колаборантами «ДНР» постраждало цивільне населення. Останнє викликало суспільний резонанс у місті. Тому українське військове керівництво прийняло рішення відступити 3 міста, 
а коли окупаційна влада продемон- суспільні настрої міста змінилися. Це струвала своє справжнє обличчя — те- дало можливість провести успішну рор, мародерство, викрадення людей, операцію по звільненню міста.

\section{Список використаних джерел і літератури}

1. 25 років незалежності: нариси історії творення нації та держави / [Г. Боряк (кер.авт.кол.), В. Головко (координатор проекту), В. Даниленко, С. Кульчицький, О. Майборода, В. Смолій (відп. ред.), Л. Якубова, С. Янішевський]; НАН України; Ін-т історії України. — К.: Ніка-Центр, 2016. — 796 с.

2. Ахметов заявил, что не знает ДНР и не позволит уничтожить Донбасс (ВИДЕО). [Електрон. ресурс]. - Режим доступа: https://www.0629.com.ua/ news/537654/ahmetov-zaavil-cto-ne-znaet-dnr-i-ne-pozvolit-unictozit-donbassvideo.

3. Біла книга антитерористичної операції на Сході України (2014-2016) / [під заг. ред. І. Руснака]. - К.: Національний університет оборони України імені Івана Черняховського, 2017. - 162 с.

4. Буткевич, Б. Атомізований креатив // Український тиждень. — 2014. № 17-18. - C. 10-12.

5. Буткевич Б. ДОНБАС. Передчуття війни // Український тиждень. - 2014.№ 16. - С. 6-7.

6. Віхров М. Дикий Схід. Нарис історії та сьогодення Донбасу. — К.: Темора, 2018. - 356 c.

7. В Мариуполе митингующие выбили дверь в горсовет (ФОТО+ВИДЕО). [Електрон. ресурс]. — Режим доступа: https://www.0629.com.ua/news/497163/vmariupole-mitinguusie-vybili-dver-v-gorsovet-fotovideo.

8. В Мариуполе на смену мирному митингу пришли протестующие против переворота в стране (ФОТО). [Електрон. ресурс]. — Режим доступа: https:// www.0629.com.ua/news/489060/v-mariupole-na-smenu-mirnomu-mitingu-prisliprotestuusie-protiv-perevorota-v-strane-foto. 
9. В Мариуполе начался митинг в поддержку Виктора Януковича, к которому в итоге записали обращение (Обновляется, ФОТО, Видео). [Електрон. ресурс]. - Pежим доступа: https://www.0629.com.ua/news/500220/v-mariupole-nacalsa-mitingv-podderzku-viktora-anukovica-k-kotoromu-v-itoge-zapisali-obrasenie-obnovlaetsafoto-video.

10. Возле горсовета Мариуполя начался митинг за проведение референдума (ФОТО+ВИДЕО+Дополняется). [Електрон. ресурс]. - Режим доступа: https:// www.0629.com.ua/news/495213/vozle-gorsoveta-mariupola-nacalsa-miting-zaprovedenie-referenduma-fotovideodopolnaetsa.

11. Донбас в огні. Путівник зоною конфлікту. - Львів, 2017. - 98 с.

12. Ильичевец. Город. 2014. № 29 (10726).

13. Ильичевец. Город. 2014. № 31 (10728).

14. Ильичевец. Город. 2014. № 40 (10737).

15. Ильичевец. Город. 2014. № 53 (10750).

16. Ильичевец. Город. 2014. № 59 (10756).

17. Лосєв І. Альянс ватніківіфраків//Українськийтиждень.—2014.№35.С. 20-21.

18. Казанський Д. Як КПУ сприяє сепаратизму // Український тиждень. 2014. № 40. [Електрон. peсурс]. — Режим доступу : https://tyzhden.ua/Politics/120457.

19. Казанський Д. Хто керує донецьким бунтом? // Український тиждень. 2014. — № 21. С. 8-9.

20. Кузьо Т. Війна Путіна проти України. Революція, націоналізм і криміналітет. — К.: ДУХ І ЛІТЕРАТУРА, 2018. — 560 с.

21. Мариупольцы за мир и порядок, единую и неделимую Украину, - заявил Хотлубей. [Електрон. ресурс]. — Режим доступа: https://www.0629.com. ua/news/512354/mariupolcy-za-mir-i-poradok-edinuu-i-nedelimuu-ukrainu-zaavilhotlubej.

22. Марко С. Хроніка гібридної війни. - К.: Альтерпрес, 2016. - 236 с., іл.

23. Нет войне! Под стенамигорсоветасобрались сотни мариупольцев за единую Украину (ФОТО+Текст обращения+Дополнено). [Електрон. ресурс]. - Режим доступа: https://www.0629.com.ua/news/488931/net-vojne-pod-stenami-gorsovetasobralis-sotni-mariupolcev-za-edinuu-ukrainu-fototekst-obraseniadopolneno. 
24. Один из лидеров ДНР заявил, что они не будут отсоединяться от Украины. [Електрон. ресурс]. - Режим доступа: https://www.0629.com.ua/news/532244/ odin-iz-liderov-dnr-zaavil-cto-oni-ne-budut-otsoedinatsa-ot-ukrainy.

25. ОО «Искренность» отрицает свою причастность к киевскому антимайдану. [Електрон. ресурс]. - Режим доступа: https://www.0629.com.ua/news/745463/ oo-iskrennost-otricaet-svou-pricastnost-k-kievskomu-antimajdanu.

26. Перепелиця Г. Україна-Росія: війна в умовах співіснування К.: Видавничий дім «Стилос», 2017. 880 с.

27. Приазовский рабочий. 2014. № 28 (19802).

28. Приазовский рабочий. 2014. № 32 (19806).

29. Приазовский рабочий. 2014. № 38 (19812).

30. Приазовский рабочий. 2014. № 43 (19817).

31. Приазовский рабочий. 2014. № 45 (19819).

32. Приазовский рабочий. 2014. № 63 (19837).

33. Приазовский рабочий. 2014. № 64 (19838).

34. Приазовский рабочий. 2014. № 66 (19840).

35. Приазовский рабочий. 2014. № 67 (19841).

36. Приазовский рабочий. 2014. № 70 (19844).

37. Приазовский рабочий. 2014. № 71 (19845).

38. Приазовский рабочий. 2014. № 72 (19846)

39. Приазовский рабочий. 2014. № 75 (19849)

40. Приазовский рабочий. 2014. № 81 (19855).

41. Смолій В., Якубова Л. Історичний контекст формування проекту русский мир та практика його реалізації в Криму й на Донбасі (Аналітична записка). - К., 2018. — 144 с.

42. Цыганок А. Донбасс: неоконченная война. Гражданская война на Украине (2014-2016): русский взгляд. - М., 2016. — 680 с.

43. Шибалов С. «ДНР» зсередини. Короткий лікнеп // Дзеркало тижня. 2014. № 34. [Електрон. ресурс]. - Режим доступу: https://dt.ua/internal/dnr-zseredinikorotkiy-liknep-_.html.

44. Якубова Л. «Русский мир» в Україні: на краю прірви. — К.: ТОВ «Видавництво «Кліо», 2018. - 384 с. 


\section{References}

1. 25 rokiv nezalezhnosti: narysy istorii tvorennia natsii ta derzhavy / [H. Boriak (ker.avt.kol.), V. Holovko (koordynator proektu), V. Danylenko, S. Kulchytskyi, O. Maiboroda, V.Smolii (vidp.red.), L. Yakubova, S. Yanishevskyi]; NAN Ukrainy; In-t istorii Ukrainy. - K.: Nika-Tsentr, 2016. - 796 s.

2. Akhmetov zaiavyl, chto ne znaet DNR y ne pozvolyt unychtozhyt Donbass (VYDEO). [Elektron.resurs]. — Rezhymdostupa: https://www.0629.com.ua/news/537654/ ahmetov-zaavil-cto-ne-znaet-dnr-i-ne-pozvolit-unictozit-donbass-video.

3. Bila knyha antyterorystychnoi operatsii na Skhodi Ukrainy (2014-2016) / [pid zah. red. I. Rusnaka). - K.: Natsionalnyi universytet oborony Ukrainy imeni Ivana Cherniakhovskoho, 2017. - 162 s.

4. Butkevych B. Atomizovanyi kreatyv // Ukrainskyi tyzhden. 2014. № 17-18. S. 10-12.

5. Butkevych B. DONBAS. Peredchuttia viiny // Ukrainskyi tyzhden. 2014. № 16. S. 6-7.

6. Vikhrov M. Dykyi Skhid. Narys istorii ta sohodennia Donbasu. - K.: Temora,2018. $-356 \mathrm{~s}$.

7. V Maryupole mytynhuiushchye vыbyly dver v horsovet (FOTO+VYDEO). [Elektron. resurs]. - Rezhym dostupa: https://www.0629.com.ua/news/497163/v-mariupole-mitinguusie-vybili-dver-v-gorsovet-fotovideo.

8. V Maryupole na smenu myrnomu mytynhu pryshly protestuiushchye protyv perevorota v strane (FOTO). [Elektron. resurs]. - Rezhym dostupa: https://www.0629. com.ua/news/489060/v-mariupole-na-smenu-mirnomu-mitingu-prisli-protestuusieprotiv-perevorota-v-strane-foto.

9. V Maryupole nachalsia mytynh v podderzhku Vyktora Yanukovycha, k kotoromu v ytohe zapysaly obrashchenye (Obnovliaetsia, FOTO, Vydeo). [Elektron. resurs]. Rezhym dostupa: https://www.0629.com.ua/news/500220/v-mariupole-nacalsa-miting-v-podderzku-viktora-anukovica-k-kotoromu-v-itoge-zapisali-obrasenie-obnovlaetsa-foto-video.

a. 10. Vozle horsoveta Maryupolia nachalsia mytynh za provedenye referenduma 
(FOTO+VYDEO+Dopolniaetsia). [Elektron. resurs]. - Rezhym dostupa: https:// www.0629.com.ua/news/495213/vozle-gorsoveta-mariupola-nacalsa-miting-za-provedenie-referenduma-fotovideodopolnaetsa.

10. Donbas v ohni. Putivnyk zonoiu konfliktu. - Lviv, 2017. - 98 s.

11. Ylychevets. Horod. 2014. № 29(10726).

12. Ylychevets. Horod. 2014. № 31 (10728).

13. Ylychevets. Horod. 2014. № 40 (10737).

14. Ylychevets. Horod. 2014. № 53 (10750).

15. Ylychevets. Horod. 2014. № 59 (10756).

16. Losiev I. Alians vatnikiv i frakiv // Ukrainskyi tyzhden. 2014.№ 35. S. 20-21.

17. Kazanskyi D. Yak KPU spryiaie separatyzmu // Ukrainskyi tyzhden. 2014. № 40. [Elektron. resurs]. — Rezhym dostupa : https://tyzhden.ua/Politics/120457.

18. Kazanskyi D. Khto keruie donetskym buntom? // Ukrainskyi tyzhden. 2014.№ 21. S. 8-9.

19. Kuzo T. Viina Putina proty Ukrainy. Revoliutsiia, natsionalizm i kryminalitet. K.: DUKh I LITERATURA, 2018. - $560 \mathrm{~s}$.

20. Maryupoltsы za myr y poriadok, edynuiu y nedelymuiu Ukraynu, - zaiavyl Khotlubei. [Elektron. resurs]. — Rezhym dostupa: https://www.0629.com.ua/news/512354/ mariupolcy-za-mir-i-poradok-edinuu-i-nedelimuu-ukrainu-zaavil-hotlubej.

21. Marko S. Khronika hibrydnoi viiny. - K.: Alterpres, 2016. - 236 s., il.

22. Net voine! Pod stenamy horsoveta sobralys sotny maryupoltsev za edynuiu Ukraynu (FOTO+Tekst obrashchenyia+Dopolneno). [Elektron. resurs]. Rezhym dostupa: https://www.0629.com.ua/news/488931/net-vojne-pod-stenami-gorsoveta-sobralis-sotni-mariupolcev-za-edinuu-ukrainu-fototekst-obraseniadopolneno.

23. Odyn yz lyderov DNR zaiavyl, chto ony ne budut otsoedyniatsia ot Ukraynы. [Elektron. resurs]. — Rezhym dostupa: https://www.0629.com.ua/news/532244/ odin-iz-liderov-dnr-zaavil-cto-oni-ne-budut-otsoedinatsa-ot-ukrainy.

24. OO «Yskrennost» otrytsaet svoiu prychastnost k kyevskomu antymaidanu. [Elektron. resurs]. — Rezhym dostupa: https://www.0629.com.ua/news/745463/ooiskrennost-otricaet-svou-pricastnost-k-kievskomu-antimajdanu. 
25. Perepelytsia H. Ukraina-Rosiia: viina v umovakh spivisnuvannia K.: Vydavnychyi $\operatorname{dim} \ll$ Stylos», 2017. $880 \mathrm{~s}$.

26. Pryazovskyi rabochyi. 2014. № 28 (19802).

27. Pryazovskyi rabochyi. 2014. № 32 (19806).

28. Pryazovskyi rabochyi. 2014. № 38 (19812).

29. Pryazovskyi rabochyi. 2014. № 43 (19817).

30. Pryazovskyi rabochyi. 2014. № 45 (19819).

31. Pryazovskyi rabochyi. 2014. № 63 (19837).

32. Pryazovskyi rabochyi. 2014. № 64 (19838).

33. (Pryazovskyi rabochyi. 2014. № 66 (19840).

34. Pryazovskyi rabochyi. 2014. № 67 (19841).

35. Pryazovskyi rabochyi. 2014. № 70 (19844).

36. Pryazovskyi rabochyi. 2014. № 71 (19845).

37. Pryazovskyi rabochyi. 2014. № 72 (19846)

38. Pryazovskyi rabochyi. 2014. № 75 (19849)

39. Pryazovskyi rabochyi. 2014. № 81 (19855).

40. Smolii V., Yakubova L. Istorychnyi kontekst formuvannia proektu russkyi myr ta praktyka yoho realizatsii v Krymu y na Donbasi (Analitychna zapyska). K., 2018. - $144 \mathrm{~s}$.

41. Tsыhanok A. Donbass: neokonchennaia voina. Hrazhdanskaia voina na Ukrayne (2014-2016): russkyi vzghliad. - M., 2016. - $680 \mathrm{s.}$

42. Shybalov Ye. «DNR» zseredyny. Korotkyi liknep // Dzerkalo tyzhnia. 2014. № 34. [Elektron. resurs]. - Rezhym dostupa: https://dt.ua/internal/dnr-zseredinikorotkiy-liknep-_.html.

43. Iakubova L. «Russkyi myr» v Ukraini: na kraiu prirvy. - K.: TOV «Vydavnytstvo «Klio», 2018. - 384 s. 
Benchuk V.O., graduate student of National

University of Ostroh Academy (Ostroh)

\section{SOCIO-POLITICALAND FORCEFUL CONFRONTATION IN UKRAINIAN CITY MARIUPOL IN SPRING 2014}

Events that took place on the East of Ukraine after Maidan and the conquest of Crimea by Russia are considered as separatism movement, which has become a military conflict. However, there is still no clear difference between these notions, as these events haven't been studied and rethought enough. On this regard, the social - political and violent confrontation on Donbas in February - June 2014 has been analyzed and represented in the article, by the example of Mariupol - a city of Azov region with thousands people.

Based on the received information it has been found out that events on Donbas was difficult and ambiguous page in the Ukrainian history, which needs to be studied profoundly and without prejudice. It has been discovered that a part of marginal social organizations together with Communist Party of Ukraine, being collaborators, were supporting the Pro-Russian movement. However, their aim was ambiguous, as each of them was following their own goal - some were inviting Russian military forces to Mariupol, another part sought to join Russian Federation, some wanted an autonomy for Donbas as a part of Ukraine. The local power, striving to keep peace and safety in the city, at the same time was supporting a part of the Pro-Russian demands, in order to put a pressure on the central authority and to keep its influence on the positions in such a way. However, as opposed to the ProRussian the part of Mariupol's population, with the support of political par- ties, whose leaders were in power in Kyiv, were speaking out against the aggres- sion of Russian Federation and standing for the territorial integrity of Ukraine.

Nonetheless, social political conflict grew into the forceful confrontation when sabotage groups, managed by Russian special services, occupied a number of cities of Donbas, which has led to the creation of "DNR". It has been specified that the capture of Mariupol by the militants was successful due to the organized provo- 
cation on the 9th May, when during the forceful confrontation between Ukrainian military forces and "DNR" collaborators the local population has suffered. The last one has woken a social resonance in the city. On this regard, the Ukrainian military leadership took a decision to retreat from the city, and when the occupational power has revealed its true colors - terror, looting, kidnapping - social attitudes have changed. It gave an opportunity to lead a successful operation on liberation of the city.

Key words: DNR, Mariupol, rally, pro-russian activists, confrontation, referendum. 